Vol. 7 No. 1 Mei 2018

E-ISSN: 2502-3101 P-ISSN: 2302-528x http://ojs.unud.ac.id/index.php/jmhu

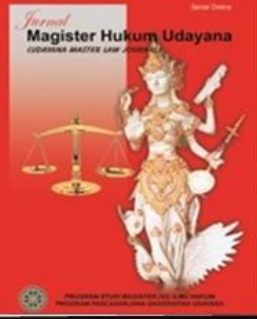

\title{
Karya Cipta Ekspresi Budaya Tradisional: Studi Empiris Perlindungan Tari Tradisional Bali di Kabupaten Bangli
}

\author{
Ida Ayu Sukihana1, I Gede Agus Kurniawan²
}

${ }^{1}$ Fakultas Hukum Universitas Udayana, Denpasar, E-mail: sukihana@yahoo.com 2 BPR Gianyar, Gianyar, E-mail : aguskurniawan2015@gmail.com

\begin{tabular}{l}
\hline Info Artikel \\
\hline Masuk : 22 Maret 2018 \\
Diterima : 21 Mei 2018 \\
Terbit : 28 Mei 2018 \\
Keywords : \\
Copyright, Traditional \\
Cultural Expressions, Legal \\
Protection \\
\\
Torresponding Author: \\
Ida Ayu Sukihana, E-mail: \\
sukihana@yahoo.com \\
Do5 : \\
Karya Cipta, Tari Tradisional \\
Bali, Ekspresi Budaya \\
Hudisional, Perlindungan \\
\end{tabular}

\begin{abstract}
Traditional Knowledge and Traditional Cultural Expression including traditional dance are constituted as cultural heritage of the ancestor which derived from generation to generation, high value and useful, therefore very important to protect. The purpose of this paper is to elaborate the implementation of Article 38 of Law No. 28 of 2014 on Copyright (Indonesia Copyright Law) related to traditional Balinese dance. This writing uses empirical legal research method. Traditional dance art as part of the traditional cultural expression is protected under Article 38 of Indonesia Copyright Law. In its implementation in Bangli regency, this provision has not been implemented effectively. One of the factors is because the community does not have a deep understanding on the substance specifically the importance of conducting inventory and documentation in the framework of legal protection through government cooperation with the community and related parties.
\end{abstract}

Abstrak
Pengetahuan Tradisional dan Ekspresi Budaya Tradisional
termasuk seni tari tradisional merupakan warisan budaya
dari leluhur yang diturunkan dari generasi ke generasi
berikutnya, bernilai dan memiliki daya guna yang tinggi,
oleh karenanya sangat penting untuk dilindungi. Tujuan
tulisan ini untuk mengelaborasi implementasi Pasal 38
Undang-Undang No. 28 Tahun 2014 tentang Hak Cipta
(UUHC 2014) berkaitan tari tradisional Bali. Penulisan ini
menggunakan metoda penelitian hukum empiris. Seni tari
tradisional sebagai ekspresi budaya tradisional dilindungi
berdasarkan Pasal 38 UUHC 2014 . Dalam implementasinya
di Kabupaten Bangli, ketentuan ini belum terlaksana secara
efektif. Salah satu faktor penyebabnya adalah masyarakat
baru sebatas mengetahui, namun belum memahami
substansinya, termasuk pemahaman tentang pentingnya
melakukan inventarisasi dan dokumentasi dalam rangka
perlindungan hukum melalui kerjasama pemerintah
dengan masyarakat serta pihak terkait.




\section{Pendahuluan}

Tumbuh dan berkembangnya suatu karya cipta tradisional di suatu daerah yang pada umumnya dikembangkan secara turun temurun dari suatu generasi ke generasi berikutnya, tidak dapat dilepaskan keberadaannya dari pengetahuan tradisional yang dikenal oleh masyarakat di daerah tersebut. Pengetahuan Tradisional (PT) serta karya cipta tradisional yang dalam konteks hukum hak cipta dikenal dengan istilah Ekspresi Budaya Tradisional (EBT) sesungguhnya merupakan warisan budaya tradisional yang tidak ternilai, amat berharga dan memilki nilai ekonomi yang tinggi. Sehubungan dengan hal tersebut, menjadi sangat penting untuk senantiasa dijaga dan dilestarikan agar jangan terkikis oleh arus budaya modern termasuk mencegah kemungkinan tertransformasikannya karya EBT tersebut melalui sarana budaya modern tanpa sepengetahuan dan izin dari masyarakat local yang mengembangkan dan melestarikan karya EBT.

Karya EBT pada awalnya dikenal dengan sebutan folklore atau folklore. Menurut WIPO Performances and Phonograms Treaty (WIPO) dan United Nations Educational Scientific and Cultural Organization (UNESCO), istilah folklor atau folklore, juga dikenal dengan sebutan Traditional Cultural Expressions (TCEs) dan Expressions of Folklore. ${ }^{1}$ Di Indonesia istilah folklore sudah tidak dipergunakan lagi dengan diundangkannya Undang-Undang Nomor 28 Tahun 2014 Tentang Hak Cipta (UUHC 2014) diganti dengan istilah Ekspresi Budaya Tradisional (EBT). Perlindungan EBT di Indonesia diatur melalui UUHC 2014 yang merupakan salah satu rezim dari hukum Kekayaan Intelektual (KI). Karya-karya EBT sangat beragam bentuk dan wujudnya, cakupannya sangat luas bisa terekspresikan dalam bentuk makanan tradisional hingga karya tari tradisional. Sepanjang masyarakat lokal pada tempat pengetahuan tradisional tersebut tumbuh dan berkembang mampu mewujudkan dan mengekspresikan menjadi suatu karya ekspresi nyata yang bersumber dari pengetahuan tradisional maka termasuk dalam lingkup karya EBT.

Pengetahuan Tradisional jika dikaji secara mendalam sesungguhnya memiliki nilai strategis bagi Indonesia yaitu baik dari aspek budaya, sosial maupun ekonomi. Dari segi budaya, perlindungan pengetahuan tradisional akan dapat meningkatkan pelestarian maka budaya bangsa. Dari aspek sosial, perlindungan pengetahuan tradisional akan memungkinkan lestarinya nilai-nilai social yang dianut oleh suatu masyarakat, mengenai apa yang dianggap baik dan apa yang dianggap buruk., termasuk nilai-nilai social yang berkaitan dengan kebiasaan, kepercayaan (believe), simbol-simbol, dengan karakteristik tertentu yang dapat dibedakan satu dan lainnya. Nilai strategis berkaitan dengan ekonomi, perlindungan terhadap pengetahuan tradisional sangat potensial meningkatkan nilai tambah devisa negara. ${ }^{2}$ Nilai strategis pengetahuan tradisional berkaitan dengan aspek ekonomi akan semakin tampak manakala pengetahuan tradisional tersebut sudah diekspresikan menjadi karya ekspresi budaya tradisional (EBT).

1 Melianti, Y., Ivanna, J., \& Perangin-angin, R. B. B. (2016). Pengaturan Folklor Secara Sui Generis Dalam Undang-undang Tersendiri. Masalah-Masalah Hukum. 45(1). 76.

2 Eta, Y. (2016). Rancangan Undang-undang Pengetahuan Tradisional dan Ekspresi Budaya Tradisional Ditinjau dari Aspek Benefits Pasal 8j Uncbd. Arena Hukum. 7(3). 461. 
Pemahaman tentang lingkup dan cakupan suatu karya dapat dikategorisasikan sebagai karya EBT dapat dicermati dari The World Intellectual Property Organization (the WIPO) yang menentukan bahwa Traditional Cultural Expressions (TCEs ) atau Expression of Folklore karakteristiknya berupa karya ekspresi dari budaya tradisional, mengandung identitas warisan budaya tradisional serta nilai-nilai kearifan masyarakat lokal, yang mencerminkan pengetahuan dan keterampilan dan ditransformasikan dari nilai-nilai mendasar dan keyakinannya melalui suatu karya ekspresi budaya tradisional (know-how and skill, and they transmit core values and beliefs). Meskipun EBT perlindungannya sudah diatur baik secara nasional maupun internasional, namun tetap menjadi topik perdebatan hangat karena para penstudi, khususnya para cendekia dari negara-negara berkembang (developing countries) tempat dimana EBT tersebut tumbuh dan dilestarikan menganggap bahwa rezim hukum kekayaan intelektual belum mampu melindungi karya EBT secara memadai, oleh karenanya perlindungan secara Sui Generis menjadi penting untuk diwujudkan. ${ }^{3}$

Perlindungan EBT secara Sui Generis memang menjadi harapan negara berkembang yang khususnya banyak memiliki karya-karya EBT dan Pengetahuan Tradisional tidak hanya yang berkaitan dengan seni namun juga berkaitan dengan obat-obatan. Indonesia sampai saat sekarang ini di pertengahan tahun 2018, perlindungan EBT secara Sui Generis masih dalam taraf Rancangan Undang-Undang RUU). Sebagai hukum positif, saat ini Indonesia masih mengatur perlindungan EBT melalui rezim hukum kekayaan intelektual, khususnya melalui ketentuan Pasal 38 UUHC 2014. Meskipun acapkali masih dikritisi perlindungan EBT melalui rezim hukum kekayaan intelektual karena ketidakmampuannya memberikan perlindungan yang memadai, namun situasinya adalah jauh lebih baik ada pengaturan perlindungan meskipun belum maksimal, daripada tidak ada sama sekali. Sehubungan dengan hal tersebut, studi ini lebih memfokuskan pada aspek pemahaman masyarakat tentang perlindungan EBT serta penegakan hukum dari ketentuan perlindungan EBT, khususnya di tengah kehidupan masyarakat yang diterpa arus globalisasi dan modernisasi dengan kemajuan teknologi informasi yang tidak dapat dibendung.

Sebagaimana telah dikemukakan sebelumnya, keberadaan karya EBT sangat beragam, namun dalam kajian ini penekanannya pada karya EBT di bidang tari Tradisional Bali. Sebagai daerah tujuan wisata, Bali sangat terkenal dengan seni budayanya, salah satunya adalah seni tari tradisional Bali, termasuk yang tumbuh, berkembang dan dilestarikan di Kabupaten Bangli sebagai salah satu bentuk karya ekspresi budaya tradisional. Salah satu penciri dari karya EBT adalah sifatnya yang komunal, yang membedakannya dengan karya cipta individual. Sehubungan dengan hal tersebut, tari tradisional Bali tentu saja tidak dimiliki oleh seorang atau beberapa orang saja, namun dimiliki oleh masyarakat setempat yang disebut dengan pengemban, sehingga masyarakat dimana eksprasi budaya tradisional itu berada yang wajib menentukan apakah diijinkan digunakan oleh pihak lain atau tidak.

Berdasarkan pemaparan dari latar belakang tersebut, maka dalam tulisan ini dielaborasi permasalahan inti: Bagaimanakah keberadaan dan implementasi Pasal 38 Undang-Undang No.28 Tahun 2014 tentang Hak Cipta berkaitan dengan

\footnotetext{
${ }^{3}$ Dharmawan, N. K. S. (2017). Protecting Traditional Balinese Weaving Trough Copyright Law: Is It Appropriate?. Diponegoro Law Review. 2(1). p. 58.
} 
perlindungan karya seni pertunjukan tari tradisional di Kabupaten Bangli ?, serta faktor - foktor yang mempengaruhi pelaksanaan perlindungan karya cipta seni pertunjukan tari tradisional sebagai EBT di Kabupaten Bangli.

Studi terdahulu yang mengkaji tentang EBT yang berkaitan dengan karya seni tradisional Bali diantaranya: Siluh Made Astini dan Usrek Tani Utina, focus kajiannya tentang slih fungsi suatu tari. Hasil studinya menunjukkan bahwa salah satu Tari tradisional di Bali, yaitu Tari Pendet beralih fungsi dari yang pada awalnya di jaman dahulu merupakan tari Pura, yaitu tari yang fungsinya untuk memuja para DewaDewi yang berstana di Pura pada saat Upacara/ Odalan, namun karena perkembangan zaman, terjadi alih fungsi pergeseran tidak hanya sebagai tari Pura, namun juga sebagai Tari Balih-Balihan, yaitu tari hiburan atau tontonan yang umumnya ditarikan untuk menyambut tamu. ${ }^{4}$ Dalam konteks yang lebih luas, Sylvana Murni D. Hutabarat mengkaji perlindungan EBT dalam perspektif Hak Kekayaan Intelektual, termasuk didalamnya perlindungan terhadap berbagai contoh karya EBT di Bali yaitu pementasan kesenian sakral, tabuh iringan tari lepas/balihbalihan, tabuh jejogedan, tabuh kreasi, tari pependetan, tari lepas/ balih-balihan, tari arja, tari janger, tari kreasi, tari kecak, sendra tari, hingga EBT yang terekspresikan dalam bentuk Upacara tradisional seperti Ngaben, hingga makanan tradisional Bali. ${ }^{5}$ Meskipun ada persamaan, yaitu sama-sama mengkaji tentang EBT yang ada kaitannya dengan karya tradisional Bali, namun focus kajiannya berbeda. Studi ini, fokusnya adalah pada penegakan hukum, khususnya bertujuan untuk mengelaborasi pemahaman masyarakat di Kabupaten Bangli tentang keberadaan perlindungan hukum EBT atas karya-karya tari tradisional yang dilestarikan di Kabupaten Bangli.

Tujuan dari penelitian ini adalah untuk mengetahui dan mengevaluasi keberadaan dan implementasi Pasal 38 Undang-Undang No.28 Tahun 2014 tentang Hak Cipta berkaitan dengan perlindungan karya seni pertunjukan tari tradisional di Kabupaten Bangli serta menganalisis faktor - faktor yang mempengaruhi pelaksanaan perlindungan karya cipta seni pertunjukan tari tradisional sebagai EBT di Kabupaten Bangli.

\section{Metode Penelitian}

Kajian tentang perlindungan EBT ini menggunakan jenis metode penelitian hukum empiris yaitu suatu penelitian positif mengenai perilaku manusia dalam masyarakat yang kemudian dihubungkan dengan norma-norma hukum normatif. Teknik pengumpulan data yang dipergunakan dalam penelitian ini adalah: Study documents yakni untuk mengumpulkan data sekunder yang terkait dengan permasalahan penelitian, dengan cara mengkaji dan menganalisis bahan hukum primer, sekunder dan tersier berkaitan dengan hak cipta dan seni pertunjukkan tradisional sebagai ekspresi budaya tradisional (EBT), serta teknik wawancara. Dalam penelitian ini dilakukan wawancara pada masyarakat di kabupaten Bangli, khususnya yang berkaitan dengan hak cipta dan seni pertunjukkan tradisional sebagai ekspresi budaya

${ }^{4}$ Astini, S. M., \& Utina, U. T. (2007). Tari Pendet Sebagai Tari Balih-Balihan (Kajian Koreografi)(Pendet Dance as Welcome Dance Coreography Research). Harmonia: Journal Of Arts Research And Education. 8(2). h. 171.

5 Hutabarat, S. M. D. (2017). Perkembangan Dan Perlindungan Pengetahuan Tradisional Dan Ekspresi Budaya Tradisional Ditinjau Dari Perspektif Hak Kekayaan Intelektual. Jurnal Yuridis. 2(2. 212 
tradisional (EBT) seperti para pemuka desa, para seniman dan pada instansi pemerintahan yang terkait dengan seni pertunjukkan tari tradisional dan ekspresi budaya tradisional (EBT) di kabupaten Bangli. Dalam hal ini sampel yang ditentukan dengan mempergunakan perporsive sampling dengan cara non-probility sampling yaitu peneliti menentukan sendiri dengan ketentuan pemilihan sampel di dasarkan pertimbangan bahwa sampel telah memenuhi kriteria dan sifat-sifat atau karakteristik tertentu yang merupakan ciri utama dari populasinya.

\section{Hasil dan Pembahasan}

\subsection{Perlindungan Ekspresi Budaya Tradisional Dalam perspektif Undang - Undang No 28 Tahun 2014}

Ekspresi Budaya Tradisional (EBT) merupakan istilah yang digunakan WIPO (World Intllectual Property Rights) dalam berbagai forum di dunia. Pemakaian istilah EBT yang dikemukakan oleh WIPO ditunjukkan untuk memberikan garisan terhadap sesuatu karya budaya yang bersifat tradisional dan dimiliki oleh masyarakat tradisional sebagai karya intelektual yang berasal dari kebudayaan tradisional milik kelompok masyarakat tradisional .Pemberian makna tersebut akan menjadi acuan untuk menetapkan suatu karya intelektual dari budaya tradisional dan mengkaitkannya pada suatu masyarakat sebagai pengemban. ${ }^{6}$

Menurut Edy Damain EBT. Merupakan suatu ciptaan dalam bidang seni yang mengandung unsur karakteristik warisan tradisional sebagai kultur bangsa yang merupakan sumberdaya bersama dikembangkan dan dipelihara atau dilestarikan oleh komunitas atau masyarakat tradisional tertentu dalam kurun waktu secara kesinambungan. ${ }^{7}$ EBT bersifat regiomagis, merupakan bentuk material yang berkembang dari generasi ke generasi dan bukan kebaharuan hanya berupa pengulangan, diampu secara komunal dan tidak selalu bermakna dalam budaya industri ${ }^{8}$ Dalam Undang-Undang Hak Cipta sebelumnya yakni Undang-Undang No,19 Tahun 2002 Ekspresi Budaya Tradisional yang juga dikenal dengan sebutan folklore dilindungi berdasarkan Pasal 10 UU. No. 19 Tahun 2002. Hingga tahun 2013 EBT di Indonesia dilindungi oleh beberapa ketentuan dalam peraturan PerundangUndangan yang tersebar. Setelah tahun 2014 dengan dikeluarkannya Undang-Undang No. 28 Tahun 2014 Tentang Hak Cipta, yang menggantikan Undang-Undang No 19 Tahun 2002, Ekspresi Budaya Tradisional dilindungi berdasarkan Pasal 38 UndangUndang No.28 Tahun 2014. Dalam ketentuan pasal ini ditegaskan bahwa dalam rangka menjaga dan memelihara keberadaan EBT, negara wajib menginventarisasikan karyakarya EBT. Lebih jauh juga diatur bahwa hak cipta atas karya EBT ada pada Negara. Secara lebih rinci Pasal 38 UUHC 2014 mengatur:

1.Hak Cipta atas Ekspresi Budaya Tradisional dipegang oleh Negara

2.Negara wajib menginventarisasi, menjaga dan memelihara Ekspresi budaya Tradisional sebagaimana dimaksud pada ayat (1).

${ }^{6}$ Indriaty, J. (2015). Perlindungan Hukum Ekspresi Budaya Tradisional Oleh Negara sebagai pemegang hak Cipta, Kekayaan Intelektual Komunal, Masyarakat Sulawesi tenggara, Dikaitkan Hak Ekonomi Berdasarkan Undang-Undang No.28 Tahun 2014 Tentang Hak Cipta. Tesis. Bandung. Program Magister ilmu Hukum, Fakultas Hukum ,Universitas Padjadjaran. h. 1.

${ }^{7}$ Damain, E. (2012). Glosarium Hak Cipta dan Hak Terkait. Alumni. Bandung. h.29.

${ }^{8} \mathrm{Ayu}$, M. R. et. al. (2014). Hukum Sumber Daya Genetik Pengetahuan Tradisional dan Ekspresi Budaya Tradisional di Indonesia. Alumni. Bandung. h. 5. 
3.Penggunaan Ekspresi Budaya Tradisional sebagaimana dimaksud pada ayat harus memperhatikan nilai-nilai budaya yang hidup dalam masyarakat pengembannya.

4.Ketentuan lebih lanjut mengenai Hak Cipta yang dipegang oleh negara atas Ekspresi Budaya Tradisional sebagaimana dimaksud pada ayat (1) diatur dengan Peraturan pemerintah.

Dengan mencermati ketentuan Pasal 38 Ayat (1) bahwa hak cipta atas EBT ada pada negara, kiranya dapat dikemukakan bahwa dalam lingkup yang lebih sempit, tidak berlebihan jika Pemerintah Daerah dapat ditafsirkan sebagai perwujudan dari Negara dimana karya EBT tersebut bertumbuh dan berkembang. Dengan demikian, keberadaan dan peran pemerintah sangat penting dan menentukan sebagai pengemban Ekspresi Budaya tradisional dalam rangka mewujudkan perlindungan dan pelestarian karya EBT, termasuk EBT di bidang seni tari tradisional. Dalam konteks ini, pemerintah daerah baik provinsi maupun kabupaten / kota memegang tugas dan fungsi penting dalam perlindungan dan pemanfaatannya. Penyelenggaraan pemerintah dalam konsep ekonomi daerah mempertegas tugas dan fungsi pemerintahan yang dibagi kewenangannya antara pemerintah pusat dengan pemerintah daerah.

Negara sebagai otoritas tertinggi dan pemerintah daerah sebagai representasi negara dalam perlindungan dan pengaturan EBT. Dapat mencegah adanya monopoli atau komersialisasi serta tindakan yang merusak atau pemanfaatan secara komersialisasi oleh pihak asing tanpa seizing negara sebagai pemegang hak Cipta. Ketentuan untuk menghindari tindakan pihak asing yang dapat merusak nilai kebudayaan tersebut dan memanfaatkan secara komersil tanpa izin dari pemilik EBT. ${ }^{9}$

Perlindungan Ekspresi Budaya Tradisional (EBT) diatur berdasarkan Pasal 38 UUHC 2014, maka EBT merupakan salah satu rezim Hak Kekayaan Intelektual (HKI), namun rezim yang konsep perlindungannya komunal. Pada umumnya konsep perlindungan hak kekayaan intelektual menganut konsep perlindungan secara individual. ${ }^{10}$ Orang yang dengan kreativitas kerja otak, yang mengorbankan waktu, tenaga, uang dan bahkan keluarga hingga menghasilkan suatu karya kreatif, termasuk di bidang seni tari, maka dalam dimensi hukum kekayaan intelektual sangat pantas diberikan perlindungan serta reward secara individual. Pengakuan terhadap hak kepemilikan secara individual juga relevan dikaitkan dengan hak asasi manusia, sebagaimana mendapat landasan fondasinya berdasarkan ketentuan Article 27 (2) Universal Declaration of Human Rights, khususnya dalam bidang Hak Cipta , ketentuan Pasal 27.2 UDHR tersebut mengatur tentang pengakuan terhadap karya ilmiah, kesastraan dan karya seni atau kesenian. ${ }^{11}$

\footnotetext{
${ }^{9}$ Indriaty, J., Loc Cit.

10 Dharmawan, N. K. S. (2011). Hak Kekayaan Intelektual Dan Harmonisasi Hukum Global (Rekonstruksi Pemikiran Terhadap Perlindungan Program Komputer). Semarang. Badan Penerbit Universitas Diponegoro. h. 43-50.

11 Supasti, N. K. (2014). Relevansi Hak Kekayaan Intelektual Dengan Hak Asasi Manusia Generasi Kedua. Jurnal Dinamika Hukum. 14(3). 520.
} 
Hak Kekayaan Intelektual merupakan sumber dari karya cipta yang dihasilkan dengan tidak mudah dan memerlukan pengorbanan baik tenaga, pikiran, waktu dan materi, maka hasil dari kekayaan intelektual tersebut perlu untuk mendapatkan perlindungan hukum. Ketentuan perlindungan hukum dari karya cipta tersebut diberikan baik pada hasil karya ciptanya maupun pada pemiliknya atau pencipta. Yang dimaksud dengan pencipta sesuai dengan Pasal 1 angka 2 UURI No. 28 Tahun 2014 tentang Hak Cipta, "pencipta adalah seorang atau beberapa orang yang secara sendiri-sendiri atau bersama-sama menghasilkan suatu ciptaan yang bersifat khas dan pribadi".

Ekspresi Budaya Tradisional merupakan salah satu ciptaan yang dilindungi melalui Pasal 38 UU Hak Cipta. Ekspresi Budaya Tradisional (EBT) mencakup salah satu atau kombinasi bentuk ekspresi sebagai berikut:

a. Verbal tekstual, baik lisan maupun tulisan, yang berbentuk prosa maupun puisi dalam berbagai tema dan kandungan isi pesan yang dapat berupa karya sastra ataupun narasi informative;

b. Musik mencakup antara lain, vocal, instrumental, atau kombinasinya;

c. Gerak, mencakup tarian;

d. Teater, mencakup antara lain : pertunjukkan wayang dan sandiwara rakyat;

e. Seni rupa, baik dalam bentuk dua dimensi ataupun tiga dimensi yang terbuat dari berbagai macam bahan seperti kulit, kayu, bambu, logam, batu, keramik, kertas, tekstil dan lain-lain atau kombinasinya dan upacara adat.

Seni pertunjukan Tari tradisional di Bali merupakan bagian penting bagi kehidupan masyarakat Bali yang sudah diwarisi sejak zaman lampau karena di Bali hamper semua upacara keagamaan harus disertai dengan tarian. Tanpa diikuti dengan tarian, maka proses upacara belum dianggap sudah selesai. Oleh karena itu pulau Bali sering mendapat julukan sebagai pulau kesenian, karena memiliki berbagai macam jenis warisan termasuk di dalamnya seni pertunjukan tari tradisional yang menurut UUHC 2014 khususnya dalam Pasal 38 huruf c..... disebut sebagai Ekspresi Budaya Tradisional.

Berkaitan dengan pertunjukan seni tari, maka I Wayan Dibia (guru besar dari Institut Seni Indonesia Denpasar) memberikan pengertian secara umum tentang seni pertunjukan pada dasarnya, adalah prestasi ide, gagasan atau pesan kepada penonton oleh perlakuannya melalui peragaan ${ }^{12}$ Di Bali seni pertunjukan tari Bali lebih cenderung merupakan tari sakral atau tari upacara yaitu tari tersebut hamper selalu dipertunjukkan pada upacara-upacara keagamaan, seperti, upacara keagamaan, dan tidak dipertunjukkan pada sembarang tempat. Seni pertunjukan tari sakral ini diterima oleh masyarakat Bali secara turun - temurun, dan sebagai warisan ekspresi budaya tradisional jika mengacu pada Pasal 38 UUHC 2014.

Kabupaten Bangli merupakan salah satu Kabupaten di provinsi Bali, sangat kaya akan seni pertunjukan tari tradisional sebagai ekspresi budaya tradisional. Kabupaten terdiri dari empat Kecamatan yakni, Kecamatan Bangli, Kecamatan Kintamani, Kecamatan Susut dan Kecamatan Tembuku. Keempat kecamatan tersebut masing-

${ }^{12}$ Dibia, I. W. (2004). Pragina: penari, aktor, dan pelaku seni pertunjukan Bali. Malang: Sava Media. h. 3 . 
masing memilki seni pertunjukan tari tradisional sebagai ekspresi budaya tradisional.dan dari keempat kecamatan yang ada didominasi oleh seni pertunjukan tari tradisional yakni tari baris dan tari sanghyang. Dari masing-masing kecamatan seni pertunjukan tari tradisional yang dapat dirangkum yakni:

\section{Kecamatan Bangli}

Baris Presi, Baris Bajra, Baris Gede, Baris perancak, Baris Jojor, Tari rejang Renteng, Tari Topeng

\section{Kecamatan Susut}

Baris juntal, Baris Pendet, Baris bedil, Jojor, Tari Rejang

\section{Kecamatan Tembuku}

Baris jangkang, Bari jojor, Baris Katekok Jago, Wayang Wong, Rejang Pendet, Janger Bobor

\section{Kecamatan Kintamani}

Baris Tombak, Baris Dadap, Baris Teruna, Sanghyang Janger Mabobor, Barong Brutuk, Sang Hyang Dewa.

Demikian banyak terdapat seni pertunjukan tari tradisional sebagai EBT di Kabupaten Bangli, dan berbagai jenis tari baris ini, adalah merupakan ciri khas dari Kabupaten Bangli, namun dari keseluruhan seni pertunjukan tari tradisional ini belum dilakukan inventarisasi sebagai bentuk perlindungan dan pelestarian dari seni pertunjukan tari tradisional tersebut. Masyarakat belum memahami sepenuhnya aspek perlindungan sebagaimana diatur dalam Pasal 38 UUHC 2014, yang salah satunya dilakukan melalui kegiatan inventarisasi sebagai salah satu bentuk pendokumentasian dalam rangka perlindungan hukum. Namun demikian, karena setiap tahun, Kabupaten Bangli bersama-sama dengan kabupaten lainnya mengikuti event Pesta Kesenian Bali (PKB), dan selalu mengikut sertakan hasil karya cipta sebagai ekspresi budaya tradisional diantaranya seni pertunjukan tari tradisional tersebut, maka secara tidak langsung ada dokumentasi yang dilakukan secara umum, namun tidak dengan format dokumentasi dalam rangka inventarisasi EBT bidang tari tradisional yang tumbuh dan berkembang serta dilestarikan di Kabupaten Bangli. Dalam realitanya, ada pihak luar yang memanfaatkan seni pertunjukan tradisional dipergunakan secara komersil, umumnya dilakukan oleh pariwisatawan dengan cara seni pertunjukan tari tradisional tersebut dipotret, di buat dalam bentuk video dan seterusnya dapat diperbanyak dalam bentuk CD atau DVD, lalu dikomersilkan di Negaranya tanpa harus meminta izin pada daerah setempat sebagai pemilik EBT tersebut.

Pembuatan video serta pemotretan karya EBT tari tradisional oleh pihak yang tidak berhak dan tanpa izin dipergunakan untuk tujuan komersial tentu saja merugikan masyarakat pengembannya. Dalam rangka meminimalisasi kejadian -kejadian sepert itu, serta meningkatkan pelindungan terhadap karya EBT, peran pemerintah Daerah, khususnya dalam kegiatan pendokumentasian sebagai salah satu bentuk pembuktian kepemilikan serta keberadaan karya EBT pada suatu daerah sangat memegang peranan penting. Sosialisasi tentang keberadaan Pasal 38 UUHC 2014 juga menjadi relevan dilaksanakan secara berkelanjutan, agar selain pemerintah melaksanakan kewajiban pendokumentasian, masyarakat juga memahami dan menyadari akan pentingnya melindungi karya-karya warisan tradisional yang bernilai tinggi yang mereka emban agar tetap lestari dan tidak dimanfaatkan oleh pihak lain yang tidak 
berhak. Menurut Endang Purwaningsih diperlukan bantuan, motivasi dan insentif Pemerintah, dalam rangka menumbuh kembangkan peran serta masyarakat dalam upaya perlindungan hukum bagi kekayaan intelektual warisan bangsa. Pemberdayaan dengan pendekatan partisipatif perlu didukung oleh penghargaan, kesadaran hukum, dan kepedulian serta kerjasama berbagai pihak. Pemerintah berperan aktif, didukung oleh masyarakat, LSM, konsultan dan kampus dalam rangka perlindungan dan pelestarian warisan budaya tradisional. ${ }^{13}$

\subsection{Faktor-faktor yang mempengaruhi Perlindungan Ekspresi Budaya Tradisional}

Faktor-faktor yang mempengaruhi penegakan hukum di Indonesia, terletak pada kegiatan menyerasikan hubungan nilai-nilai yang terjabarkan di dalam kaidah-kaidah yang mantap mengejawantah dan sikap tindak sebagai rangkaian penjabaran nilai tahap akhir. Pokok penegakan hukum sebagai perlindungan hukum secara umum dan ekspresi budaya tradisional (EBT) maka faktor-faktor yang dapat mempengaruhinya menurut Soerjono Soekanto ada lima faktor yaitu : Faktor Hukumnya sendiri, Faktor penegak hukum, Faktor sarana atau fasilitas yang mendukung penegakan hukum, Faktor masyarakat, serta Faktor kebudayaan.. Kelima faktor tersebut saling berkaitan dengan eratnya, oleh karena merupakan esensi dari penegakan hukum, yang sangat relevan dengan perlindungan hukum itu sendiri. Juga merupakan tolak ukur daripada efektifitas penegakan hukum. ${ }^{14}$

Berkaitan dengan penegakan hukum dan implementasi ketentuan Pasal 38 UUHC 2014 dalam rangka perlindungan hukum terhadap karya EBT bidang seni tari tradisional Bali di kabupaten Bangli, berdasarkan hasil studi empiris di Kabupaten bangle, ada beberapa faktor yang mempengaruhi perlindungan hukum terhadap seni pertunjukan tari tradisional sebagai ekspresi budaya tradisional di Kabupaten Bangli yakni :

\subsubsection{Faktor pemahaman hukum}

Pemahaman hukum artinya bagaimana pengetahuan hukum masyarakat di Kabupaten Bangli berkaitan dengan keberadaan Pasal 38 Tahun 2014 Tentang UndangUndang Hak Cipta. Sesuai dengan hasil penelitian di Bangli berkaitan dengan pemahaman hukum tentang hak cipta, khususnya yang berhubungan dengan seni pertunjukkan tari tradisional, bisa diklasifikasikan menjadi 2 yakni :

- Pemahaman hukum terhadap aparat pemerintah masih kurang. Hanya sebatas mengetahui keberadaan dan belum memahami betul keberadaan Undang-Undang Hak Cipta.

- Terhadap pelaku seni dan masyarakat, mereka mengemukakan bahwa mereka tidak mengetahui atau tidak memahami secara mendetail keberadaan Undang-Undang Hak Cipta. Dimana mereka hanya memperagakan tarian-tarian tradisional tersebut yang merupakan tarian turun temurun yang mereka dapatkan dan tidak diketahui siapa penciptanya. Mereka mempertunjukkan seni tari tradisional tersebut hanya

13 Purwaningsih, E. (2012). Partisipasi Masyarakat dalam Perlindungan Hukum terhadap Kekayaan Intelektual Warisan Bangsa. Masalah-Masalah Hukum. 41(1). 49.

14 Kompasmedia. (2015). http://m.kompasyana.com/jawara/faktorfaktoryangmempengaruhipenegakkanhukumdiIndonesia. Diakses 26 Juli 2016. 
sebatas pada event - event tertentu, seperti pada waktu ada upacara agama di Pura atau upacara-upcara agama lainnya. Selama ini pelaku seni belum pernah mengetahui kalau tari tradisional yang mereka tarikan sudah mendapatkan perlindungan pada Undang- Undang Hak Cipta.

\subsubsection{Faktor lingkungan}

Faktor lingkungan adalah faktor dimana aturan itu dapat diterima atau tidak diterima oleh masyarakat yang bersangkutan. Berkaitan dengan faktor lingkungan ini, baik aparat pemerintah, pelaku seni dan masyarakat belum memahami keberadaan Undang-Undang Hak Cipta, sehingga dalam perkembangannya belum pernah terjadi masalah berkaitan dengan pelanggaran seni pertunjukkan tari tradisional sebagai ekspresi budaya tradisonal (EBT).

\subsubsection{Faktor sarana dan fasilitas}

Faktor sarana dan fasilitas, sangat tergantung dengan sumber daya manusia sebagai pengemban ekspresi budaya tradisional (EBT) dan juga sumber dana sebagai pendukung.

Daerah Tk. Ll Kabupaten Bangli ada upaya bagi pemerintahnya untuk melindungi seni pertunjukkan tari tradisional sebagai ekspresi budaya tradisional (EBT), namun terbatas adanya sumber daya manusia yang memahami tentang Undang-Undang Hak Cipta. Selain faktor sumber daya manusia juga oleh faktor dana yang terbatas sehingga tidak memungkinkan untuk melakukan sosialisasi dan membuat aturan yang berkaitan dengan seni pertunjukkan tari tradisional sebagai ekspresi budaya tradisional (EBT) di kabupaten Bangli. Karena untuk membuat PERDA membutuhkan biaya yang tidak sedikit. Namun kedepannya akan diusahakan dibuatkan peraturan yang berbentuk Peraturan Daerah berkaitan dengan perlindungan seni pertunjukan tari tradisional sebagai payung hukumnya.

\subsubsection{Faktor kebudayaan}

Faktor budaya sangat dipengaruhi oleh budaya hukum bangsa Indonesia yang menganut konsep budaya hukum timur yang bersifat communal rights khususnya berkaitan dengan hukum hak kekayaan intelektual yang berarti kebersamaan. Hak milik seseorang merupakan hak milik bersama masyarakat tersebut. Berbeda halnya dengan budaya barat yang menganut budaya hukum individual rights dimana sangat menghargai hak milik individu. Apabila hak milik individu digunakan oleh orang lain wajib untuk meminta persetujuan atau izin dari pemiliknya. Demikian juga halnya dengan seni pertunjukan tari tradisional yang ada di Kabupaten Bangli. Tari tradisional yang ada di Kabupaten Bangli didominasi oleh tari Baris, karena di setiap Kecamatan yang ada di Kabupaten Bangli seperti Kecamatan Kintamani, Kecamatan Susut, Kecamatan Tembuku dan Kecamatan Bangli memiliki tari baris dan mempunyai karakter yang berbeda. Keberadaan tarian tradisional tersebut tidak memberikan batasan bagi setiap orang yang ingin menarikannya termasuk diluar daerah pengemban, tidak diwajibkan untuk meminta izin pada daerah pengemban.

\section{Kesimpulan}

Keberadaan Pasal 38 Undang-Undang NO.28 Tahun 2014 tentang Hak Cipta dan pelaksanaannya berkaitan dengan perlindungan seni pertunjukan tari tradisional di Kabupaten Bangli belum terlaksana secara efektif., disebabkan oleh beberapa faktor. 
Masyarakat baru hanya sebatas mengetahui dan belum memahami secara mendalam mengenai Undang-Undang Hak Cipta khususnya Pasal 38 dari Undang-Undang Hak Cipta tersebut. Pemahaman yang belum memadai terhadap substansi perlindungan karya Ekspresi Budaya Tradisonal juga terlihat dari belum adanya kegiatan inventarisasi karya seni pertunjukan tari tradisional sebagai ekspresi budaya tradisional di Kabupaten Bangli, karena masyarakat belum mengetahui bahwa inventarisasi dan pendokumentasian memegang peranan penting sebagai sarana kepastian hukum akan perlindungan karya ekspresi budaya tradisional yang masyarakat sebagai pengembannya. Faktor-faktor yang mempengaruhi belum terlaksananya secara efektif perlindungan karya seni tari tradisional:

Pemahaman hukumnya baik pada aparat pemerintah maupun pada pelaku seni dan masyarakat pengembannya., faktor lingkungan, faktor sarana dan fasilitas, seperti sumber daya manusia dan dana sebagai pendukung, dan faktor kebudayaan yang menganut budaya hukum komunal.

Dalam rangka perlindungan hukum serta pelestarian keberadaan karya seni tari tradisional bali di Kabupaten Bangli, sangat penting dilakukan kegiatan inventarisasi dan pendokumentasian, diharapkan peran aktif pemerintah Tingkat II Kabupaten Bangli bekerjasama dengan berbagai pihak relevan termasuk masyarakat, LSM, maupun kampus.

\section{Daftar Pustaka}

Buku

Ayu, M. R., Alexander, H. \& Puspitasari, W. (2014). Hukum Sumber Daya Genetik, Pengetahuan Tradisional dan Ekspresi Budaya Tradisional di Indonesia. Bandung: Alumni.

Damian, E. (2012). Glosarium hak cipta dan hak terkait. Bandung: Alumni.

Dharmawan, N. K. S. (2011). Hak Kekayaan Intelektual Dan Harmonisasi Hukum Global (Rekonstruksi Pemikiran Terhadap Perlindungan Program Komputer). Semarang. Badan Penerbit Universitas Diponegoro.

Dibia, I. W. (2004). Pragina: penari, aktor, dan pelaku seni pertunjukan Bali. Malang: Sava Media.

Purba, A., Saleh, G., \& Krisnawati, A. (2005). TRIPs-WTO \& hukum HKI Indonesia: kajian perlindungan hak cipta seni batik tradisional Indonesia. Jakarta: Rineka Cipta.

Riswandi, B. A., \& Syamsudin, M. (2004). Hak Kekayaan Intelektual dan Budaya Hukum. Jakarta: Raja Grafindo Persada.

Saidin, OK. (2003). Aspek Hukum Hak Kekayaan Intelektual (Intelektual Property Rights). Jakarta. PT. Raja Grafindo Persada.

\section{Jurnal}

Astini, S. M., \& Utina, U. T. (2007). Tari Pendet Sebagai Tari Balih-Balihan (Kajian Koreografi)(Pendet Dance as Welcome Dance Coreography 
Research). Harmonia: Journal Of Arts Research And Education. 8(2), 170-179. https://doi.org/10.15294/harmonia.v8i2.789

Dharmawan, N. (2017). Protecting Traditional Balinese Weaving Trough Copyright Law : Is It Appropriate?. Diponegoro Law Review, 2(1), 57-84. http://dx.doi.org/10.14710/dilrev.2.1.2017.57-84

Eta, Y. (2016). Rancangan Undang-undang Pengetahuan Tradisional dan Ekspresi Budaya Tradisional Ditinjau dari Aspek Benefits Pasal 8j Uncbd. Arena Hukum, 7(3). 458-471.

Hutabarat, S. M. D. (2017). Perkembangan Dan Perlindungan Pengetahuan Tradisional Dan Ekspresi Budaya Tradisional Ditinjau Dari Perspektif Hak Kekayaan Intelektual. Jurnal Yuridis, 2(2). 202-219.

Melianti, Y., Ivanna, J., \& Perangin-angin, R. B. B. (2016). Pengaturan Folklor Secara Sui Generis Dalam Undang-undang Tersendiri. Masalah-Masalah Hukum. 45(1). 75-84. https://doi.org/10.14710/mmh.45.1.2016.75-84

Purwaningsih, E. (2012). Partisipasi Masyarakat dalam Perlindungan Hukum terhadap Kekayaan Intelektual Warisan Bangsa. Masalah-Masalah Hukum. 41(1). 42-49. https://doi.org/10.14710/mmh.41.1.2012.42-49

Supasti, N. K. (2014). Relevansi Hak Kekayaan Intelektual Dengan Hak Asasi Manusia Generasi Kedua. Jurnal Dinamika Hukum. 14(3). 518-527. http:/ / dx.doi.org/10.20884/1.jdh.2014.14.3.323

\section{Tesis atau Desertasi}

Indriaty, J. (2015). Perlindungan Hukum Ekspresi Budaya Tradisional Oleh Negara sebagai pemegang hak Cipta,Kekayaan Intelektual Komunal,Masayarakat Sulawesi tenggara,Dikaitkan Hak Ekonomi Berdasarkan Undang-Undang No.28 Tahun 2014 Tentang Hak Cipta. Tesis. Bandung. Program Magister ilmu Hukum ,Fakultas Hukum ,Universitas Padjadjaran.

\section{$\underline{\text { Internet }}$}

Kompasmedia. (2015). $\quad$ http://m.kompasyana.com/jawara/ faktorfaktoryangmempengaruhipenegakkanhukumdiIndonesia. $\quad$ Diakses pada tanggal 26 Juli 2016. 